\title{
ОЦЕНКА ВЛИЯНИЯ ИНСОЛЯЦИИ ДЕРЕВЬЕВ НА РАСПРОСТРАНЕНИЕ И РАЗВИТИЕ КАШТАНОВОЙ МИНИРУЮЩЕЙ МОЛИ-ВРЕДИТЕЛЯ КОНСКОГО КАШТАНА ОБЫКНОВЕННОГО
}

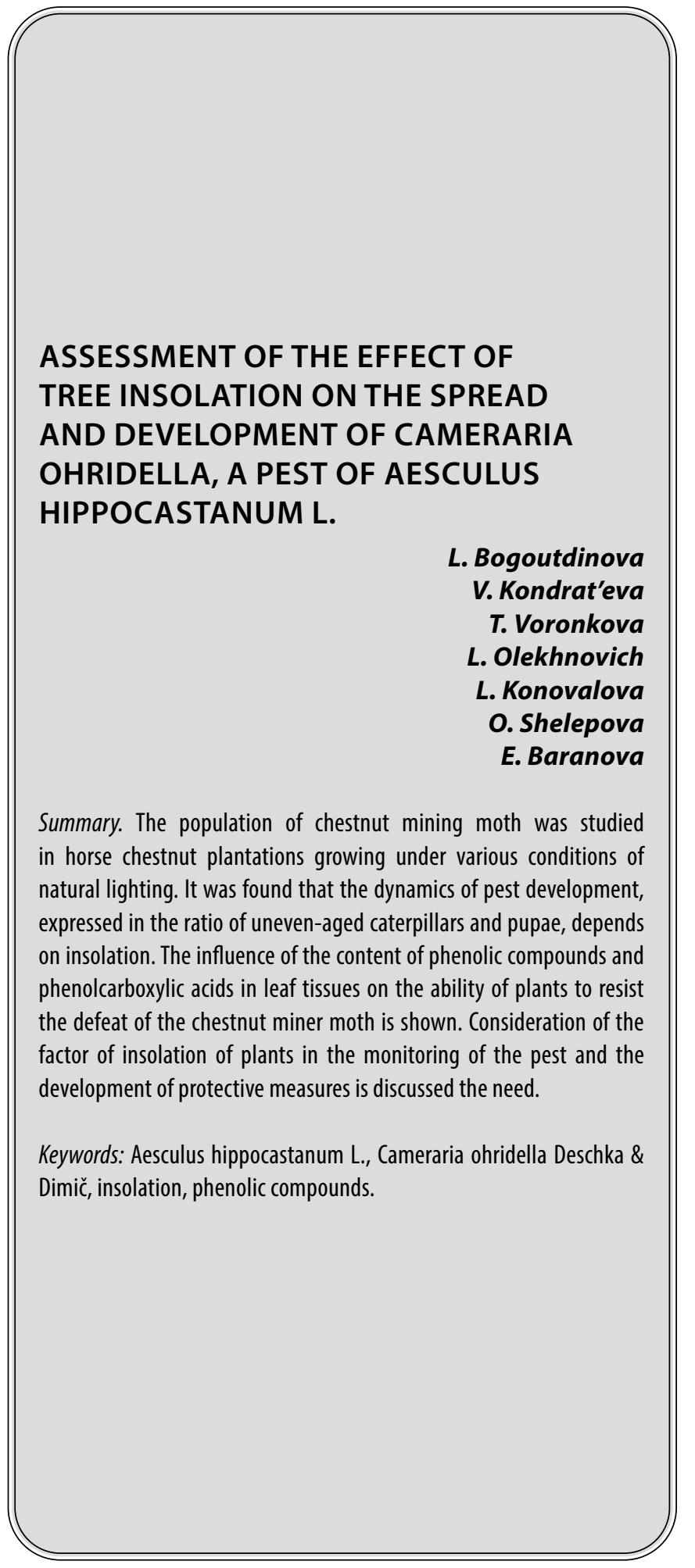

Богоутдинова Лилия Рашидовна

Аспирант, ВНИИ сельскохозяйственной

биотехнологии, Москва

bogoutdinova_Ir@rambler.ru

Кондратьева Вера Валентиновна

К.б.н., с.н.с., Главный ботанический сад

им. Н.В. Цичина РАН, Москва

lab-physiol@mail.ru

Воронкова Татьяна Владимировна

К.б.н., с.н.с., Главный ботанический сад

им. Н.В. Цицина РАН, Москва

Олехнович Людмила Сергеевна

М.н.с., Главный ботанический сад им. Н.В. Цицина

РАН, Москва

Коновалова Людмила Николаевна

Н.с., Главный ботанический сад им. Н.В. Цичина РАН,

Москва

konovalova-lu@yandex.ru

Шелепова Ольга Владимировна

К.б.н., в.н.с., Главный ботанический сад

им. Н.В. Цичина РАН, Москва

shov_gbsad@mail.ru

Баранова Екатерина Николаевна

К.б.н., в.н.С., Всероссийский научно-

исследовательский институт сельскохозяйственной биотехнологии; Главный ботанический сад им. Н.В. Цицина РАН, Москва

greenpro2007@rambler.ru

Аннотация. Изучена популяция каштановой минирующей моли в посадках конского каштана, произрастающих при различных условиях естественного освещения. Установлено, что динамика развития, выражающаяся в соотношении разновозрастных гусениц и куколок, зависит от инсоляции. Показано влияние содержания фенольных соединений и фенолкарбоновых кислот в тканях листьев на способность растений противодействовать поражению каштановой минирующей молью. Обсуждается необходимость учета фактора инсоляции растений при мониторинге вредителя и разработке защитных мер.

Ключевые слова: Aesculus hippocastanum L., Cameraria ohridella Deschka \& Dimič, инсоляция, фенольные соединения. 


\section{Ввемение}

K аштан конский Aesculus hippocastanum L.- один из видов, сохраняющих декоративность в течение всего вегетационного периода. Красивая листва, эффектная форма соцветий, их обилие, продолжительный период цветения, плотная шарообразная форма кроны создают неповторимый эстетический облик этого растения. Кроме того, каштан конский хорошо адаптирован к антропогенным условиям городской среды, что является важной составляющей при подборе древесных растений для озеленения (Голосова и Гниенко, 2006). Однако данный вид неустойчив к каштановой минирующей моли или орхидскому минеру (Cameraria ohridella Deschka \& Dimič) (Акимов и др., 2003). Особенностью биоэкологии C. ohridella является развитие личинок в обширных желто-бурых минах на листовых пластинках, хорошо заметных на фоне неповрежденных участков листвы. При интенсивном повреждении деревья быстро утрачивают декоративность, досрочно сбрасывают листья, снижают прирост, уходят на зимовку в ослабленном состоянии (Гниенко и др., 2003). Высокая вредоносность каштановой минирующей моли ставят под вопрос целесообразность не только закладки новых, но и существования имеющихся посадок каштана конского в городских зеленых насаждениях. Остается до конца не выясненным влияют ли экологические условия произрастания на численность гусениц и куколок $C$. ohridella. Разработка системы мониторинга распространения орхидного минера и защиты от него посадок каштанов должно базироваться на результатах изучения биологических особенностей и развития этих насекомых в конкретных экологических условиях, в частности от степени освещенности деревьев, что и явилось целью наших исследований.

\section{Объекты и методика}

Исследования проведены в дендрарии Московского государственного университета им. М.В.Ломоносова $\left(55.704161^{\circ}\right.$ с.ш. $37.521393^{\circ}$ в.д.). Были заложены несколько пунктов учета, отличавшихся по инсоляции. В течение вегетационного сезона на каждом учетном пункте срывали по 25 листьев каштана, выбранных рандомизировано из разных частей крон - 1) с высокой освещенностью (инсоляция до $700 \mathrm{Bт/M2)} \mathrm{и} \mathrm{2)} \mathrm{с} \mathrm{мини-}$ мальной степенью освещенности (инсоляция до 400 Вт) м2). В дальнейшем определяли возрастной состав и популяционные показатели орхидного минера, уровень поврежденности листьев и ряд физиологических показателей листьев (содержание фенольных соединений и фенолкарбоновых кислот). Суммарное содержание фенольных соединений (ССФ) определяли спектрофотометрически методом Фолина-Чокальте, согласно методике «Способ определения суммарного содержа- ния фенольных соединений в растительных образцах» (Патент RU2700787 C1). CСФ выражали в миллиграммах эквивалента галловой кислоты на 100 г растительного материала и определяли как среднее значение трех параллельных измерений. Количество хлорогеновой (ХК) и феруловой (ФК) кислот анализировали из одной навески: 2 г сырых листьев экстрагировали этанолом (80\%), экстракт упаривали до водной фазы, которую делили на две равные по объему части. Для выделения ХК и ФК экстракт очищали по модифицированной в лаборатории методике (Кондратьева и др., 2019). На заключительном этапе использовали изократическую высокоэффективную жидкостную хроматографию (изократический хроматограф Стайер, ЗАО «Аквилон», Россия) с колонкой RP-18 (250/4,6 мм) («Phenomenex, Inc.», США).

\section{Результаты и обсужление}

В московском регионе каштановый минер развивается в двух поколениях с максимумами численности в конце июня и во второй половине августа. В зависимости от температуры воздуха гусеницы каштанового минера развиваются до 30 дней при сумме эффективных температур до $250^{\circ} \mathrm{C}$, куколки - до 15 дня при 103$190^{\circ} \mathrm{C}$. Средняя продолжительность периодов между появлением бабочек первого и второго поколения составляет 42 дня; между появлением мин I и II поколений - 45 дней; между появлением куколок - 36 дней. Средняя сумма положительных температур, необходимых для развития одного поколения каштанового минера, составляет порядка $970^{\circ} \mathrm{C}$ (Мешкова и Микулина, 2012).

Результаты исследований степени пораженности листьев каштана конского орхидным минёром свидетельствуют, что листья при разной степени освещенности были сильно повреждёны минером, очаги поражения были ярко выражены и занимали большую площадь листа - до 70-75\% низкой степени освещенности листьев и до 45-50\% на листьях при высокой инсоляции (табл. 1). Согласно данным Трибель С.А. и Гамовой О.Н. (2009) повреждения орхидным минером до 25\% поверхности листа компенсируются толерантностью растения-хозяина и мало влияют на его продуктивность, а повреждения свыше 75\% поверхности часто приводят к необратимым последствиям.

При этом в ходе индивидуального развития личинок $C$. ohridella постоянно изменяется конфигурации мин, поэтому на всех листьях каштанов присутствовали мины разной формы (Рогинский и Буга, 2014; Рогинский и др.,2014). Так мины гусениц 1-го и 2-го возраста имели небольшой размер каплевидной формы (малозаметные на листьях), на 3-м и 4-м возрастах они приобре- 
Таблица 1. Популяционные средние показатели орхидных минеров и уровня поврежденности листьев каштана конского с разной степенью освещенности

\begin{tabular}{|l|l|l|}
\hline Показатель & Листья с высокой степенью освещенности & Листья с низкой степенью освещенности \\
\hline Количество гусениц, шт на лист & $13,7 \pm 0,5$ & $16,8 \pm 0,7$ \\
\hline $\begin{array}{l}\text { Количество гусениц 3 и 4-го } \\
\text { возраста, шт на лист }\end{array}$ & $3,8 \pm 0,2$ & $8,1 \pm 0,3$ \\
\hline Количество куколок, шт на лист & $7,5 \pm 0,4$ & $6,8 \pm 0,2$ \\
\hline Плотность мин на лист & $31,4 \pm 0,3$ & $46,8 \pm 0,5$ \\
\hline $\begin{array}{l}\text { Уровень поврежденности } \\
\text { листьев,\% }\end{array}$ & $41,8 \pm 0,5$ & $73,4 \pm 0,4$ \\
\hline
\end{tabular}
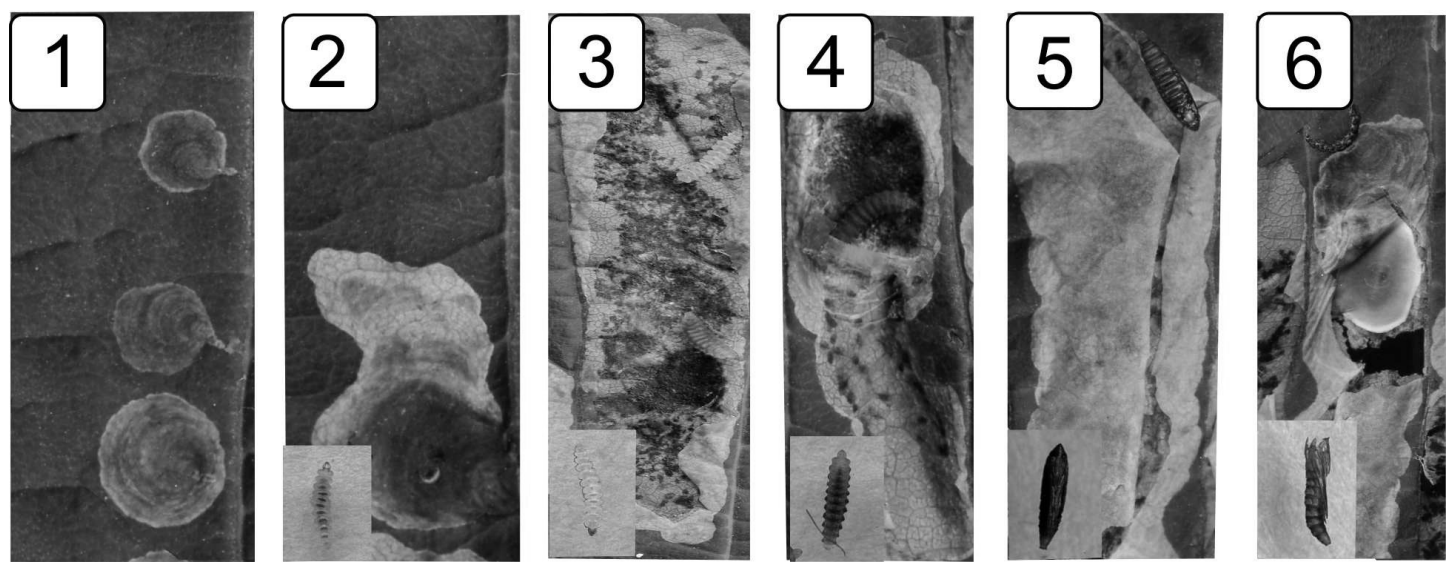

Рис. 1. Формы мин каштанового минера второго поколения разного возраста: 1-2 - мины и личинки 3 и 4-го возраста, 3-4 -личинка 5го возраста и куколка в мине; 6 - куколка коконе (зимующая стадия).

ли округло-сферическую форму, а на 5-м - мины были большого размера вытянуто-овальной формы (рис. 1 (1-5)). Окраска мин с развитием гусениц также может изменяться от серебристо-белой до темно-бурой, это сопровождается постепенным накоплением экскрементов в образовавшейся после выедания фитофагом полости столбчатой паренхимы между верхним эпидермисом листа и губчатой паренхимой. Выделяют 6-ю стадию, не питающуюся и прядущую в мине колыбельку (кокон). Наличие полного цикла с образованием кокона повышает выживаемость насекомых в период покоя (рис 1 (6)).

На листьях растений, произрастающих в различающихся световых условиях, наблюдалось перекрывание отдельных поколений. При этом количество гусениц и куколок орхидного минера на листьях каштана конского с высокой степенью освещенности было практически на одном уровне. В то время как на листьях каштана с низкой степенью освещенности зафиксировано большее количество гусениц по сравнению с куколками (табл. 1). При этом плотность мин на лист также была выше в 1,5 раза на листьях каштана с низкой степенью освещенности. Исходя из степени поражения листьев, нами были определены значения плотностей мин, при которых уровень повреждения крон превысит 25\%-8 мин/лист для каштанового минера 3 и 4-го возраста для листьев с высокой степенью освещенности и 12 мин/ лист для листьев с низкой степенью освещенности.

При этом на листьях каштана, находящихся в условиях затенения, количество гусениц на поздних стадиях (4 и 5-ой) развития было в 1,6 раз больше по сравнению с листьями, произрастающими на свету, - 44,9\% и 27,6\% от общего числа гусениц на листьях с низкой и высокой степенью освещенности, соответственно.

Сопоставление площади мин личинок разных возрастов позволяют заключить, что с четвертого возраста наблюдается лавинообразное нарастание площади повреждений, и они становятся хорошо заметны, что определяет катастрофическое падения декоративности. Поскольку потеря растениями каштана декоративности вследствие повреждения листовых пластинок этим фитофагом в течение вегетационного сезона необратима, защитные мероприятия в виде обработок (опрыскивания) системными пестицидами должны назначаться в период массового лета насекомых (на- 
чиная с массового цветения насаждений) с обеспечением мониторинга с использованием ловушек или по мере обнаружения, но до достижения личинками С. ohridella четвертого возраста. Это важно учитывать при осуществлении энтомо-фитопатологического надзора за декоративными насаждениями.

Одним из механизмов запуска и регуляции адаптационного механизма ответа растений на биотический стресс (поражение листьев орхидным минером) служат фенольные соединения. Суммарное содержание фенольных соединений (ССФ) определяли в тканях листьев, произрастающих при разной освещенности. ССФ в листья с высокой степенью освещенности варьировался от 100,11 до 118,18 мг GAE / 100 г и в среднем соста-

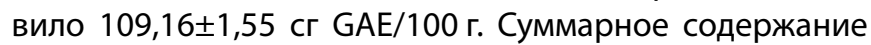
фенольных соединений в листьях с низкой степенью освещенности было в 1,8 раза выше, оно изменялось в пределах от 189,14 до 201,87 мг GAE / 100 г и в сред-

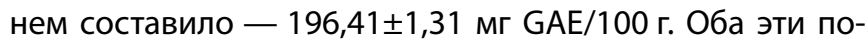
казателя существенно выше уровня фенольных кислот (40-120 мг / г) в листьях других видов каштанов, не поражаемых орхидным минером (Пентелюк и др., 2016).

Следует отметить, что в запуске каскадных реакций, включающих разные пути активации защитных механизмов, играют фенолкарбоновые кислоты (ФФК). Одними из триггеров защитного сигнального пути служат феруловая и хлорогеновая кислоты. Их роль в запуске и регуляции адаптационного механизма неоднозначна (Oszmianski et al., 2014; Oszmianski et al., 2015). Избыток хлорогеновой и феруловой кислот может вызвать усиление стрессового воздействия, что мы и наблюдали на листьях при пониженной степенью освещенности. Содержание феруловой кислоты в листьях при пони- женной степенью освещенности было практически в 3,7 раза выше по сравнению с листьями при высокой

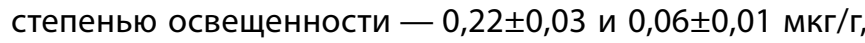
соответственно мкг/г, соответственно. А хлорогеновой кислоты в аналогичных условиях было практически

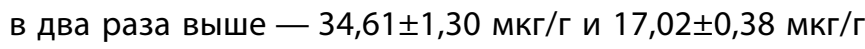
в листьях с высокой и низкой инсоляцией, соответственно.

Возможно, изменение статуса фенолкарбоновых кислот и фенольных соединений в тканях листьев при высокой степени освещенности способствовало включению протекторного каскада реакций, которые в некоторой степени нивелировали негативные последствия заселения листьев орхидным минером, что отразилось в меньшей степени пораженности листьев. Изменение соотношения ССФ и ФФК в листьях при низкой степени освещенности не вовлекалось в экспрессию защитных генов, и, следовательно, не дало положительного эффекта и не способствовало переключению метаболических процессов на адаптационный режим.

Таким образом, в московском регионе каштановый орхидный минер развивается в двух поколениях. Первые мины каштанового минеров появляются после полного облиствения деревьев. Уровень поврежденности листьев, средняя плотность мин на листьях, содержания фенольных соединений и фенолкарбоновых кислот в тканях листьев была выше на листьях с низкой инсоляцией, чем на хорошо освещенных листьях. Уровень повреждения крон минерами превышает 25\% при плотности мин каштанового минера 8 мин/лист для каштанового минера 3 и 4-го возраста для листьев с высокой степенью освещенности и 12 мин/лист для листьев с низкой степенью освещенности.

\section{ЛИТЕРАТУРА}

1. Акимов И.А., Зерова М.Д., Нарольский Н.Б., Свиридов С.В., Коханец А.М., Никитенко Г.Н., Гершензон З.С. Биология каштановой минирующей моли Cameraria ohridella (Lepidoptera, Gracillariidae) в Украине // Вестник зоологии, 2003, т. 37, № 5, c. 41-52.

2. Гниненко, Ю.И., Голосова, М.А., Жуков, А.М. Состояние конского каштана обыкновенного в некоторых странах Европы //Лесохозяйственная информация Министерства природных ресурсов, 2003, № 7. с. 61-63.

3. Голосова, М.А., Гниненко, Ю.И. Появление охридского минера на конском каштане в Москве //Лесной вестник, 2006, N2. с. 43-46.

4. Кондратьева В.В., Воронкова Т.В., Олехнович Л.С., Бидюкова Г.Ф., Енина 0.Л., Шелепова 0.В. Устойчивость рассады декоративных растений к кратковременному холодовому стрессу при воздействии узкоспектрального света // Сельскохозяйственная биология, 2019, т. 54, № 1, с. 121-129.

5. Мешкова В.Л., Микулина И.Н. Сезонное развитие инвазионных молей-минеров в зеленых насаждениях г. Харькова. // Экологические и экономические последствия инвазий дендрофильных насекомых. Материалы Всероссийской конференции с международным участием. Красноярск, 25-27 сентября 2012 г. Красноярск: ИЛ СО РАН, 2012, с. 168-172.

6. Николаева Т.Н., Лапшин П.В., Нечаева Т.Л., Загоскина Н.В. Способ определения суммарного содержания фенольных соединений в растительных образцах / Патент RU2700787 С1, дата публикации 23.03.2019

7. Пентелюк Е.С., Лиханов А.Ф., Григорюк И.А. Динамика содержания полифенолов в листьях растений каштана конского (Aesculus hippocastanum L.) в условиях механических повреждений //Биоресурсы и природопользование, 2016, т. 8, № 1-2, с. 3-12.

8. Рогинский А.С., Буга С.В. Поврежденность каштана конского обыкновенного каштановой минирующей молью (Cameraria ohridella Deschka \& Dimič, 1986) в условиях зеленых насаждений г. Минска в осенний период // Защита растений, 2014, № 38, с. 216-225. 
9. Рогинский А.С., Синчук О.В., Сауткин Ф.В., Буга С.В. Распространение и вредоносность каштановой минирующей моли (Cameraria ohridella Deschka \& Dimič) в зеленых насаждениях Беларуси // Труды БГУ, 2014. т. 9, ч. 2, с. 95-103.

10. Трибель С.А., Гаманова 0.Н. Мониторинг каштановой минирующей моли // Защита и карантин растений, 2009, № 2, с. 45-47.

11. Oszmianski J., Kalisz S., Aneta W. The content of phenolic compounds in leaf tissues of white (Aesculus hippocastanum L.) and red horse chestnut (Aesculus carnea H.) colonized by the horse chestnut leaf miner (Cameraria ohridella Deschka \& Dimic) // Molecules, 2014, v. 19., p.14625-14636.

12. Oszmianski J., Kolniak-Ostek J., Biernat A. The content of phenolic compounds in leaf tissues of Aesculus glabra and Aesculus parviflora Walt. // Molecules, 2015, v. 20, p. 76-89.

( С Богоутдинова Лилия Рашидовна ( bogoutdinova_Ir@rambler.ru ), Кондратьева Вера Валентиновна ( lab-physiol@mail.ru ), Воронкова Татьяна Владимировна, Олехнович Людмила Сергеевна, Коновалова Людмила Николаевна (konovalova-lu@yandex.ru ), Шелепова Ольга Владимировна ( shov_gbsad@mail.ru ), Баранова Екатерина Николаевна ( greenpro2007@rambler.ru ). Журнал «Современная наука: актуальные проблемы теории и практики»

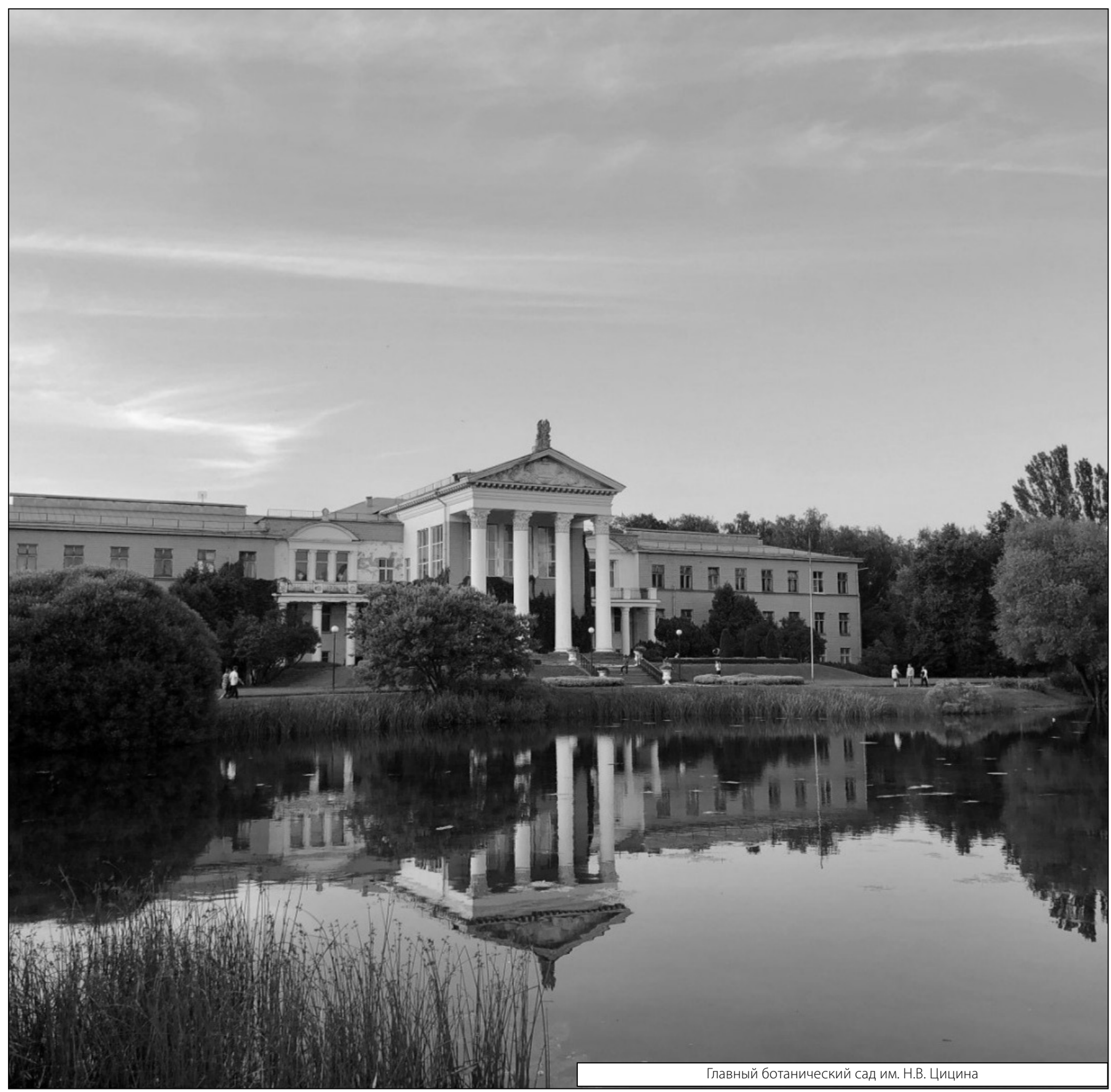

